\title{
Dietary intakes, resting metabolic rates, and body composition in benign and malignant gastrointestinal disease
}

\author{
M BURKE, ELAINE I BRYSON, A E KARK
}

\section{Summary and conclusions}

Dietary protein and energy. intakes were assessed in 42 patients with cancer and 24 with benign conditions of the gastrointestinal tract. The relation of dietary intake to body composition was examined. Resting metabolic rate was measured in 51 patients. No significant differences in dietary intake or metabolic rate were found between patients with cancer and those with benign disease. There were significant positive correlations between protein and energy intakes and the ratio of total body potassium to total body water in patients with benign disease but not in those with cancer.

Weight loss was probably due to inadequate food intake, the main defect being energy deficiency, since protein intake was usually well maintained. Supplementing with energy the voluntarily ingested diet of patients with cancer would probably prevent weight loss in most cases.

\section{Introduction}

The importance of undernutrition in the morbidity and mortality associated with cancer has been recognised for many years. Cachexia has been cited as the most common cause of death in patients with cancer. ${ }^{1}$ Malignant cachexia is characterised by loss of body tissue, redistribution of body compartments, hormonal changes, and progressive multi-organ failure. As with most conditions associated with weight loss, it probably results from longstanding excess of energy output over energy intake. Many workers have studied metabolic rates and energy expenditure ${ }^{2-9}$ but relatively few have compared the dietary intakes of patients with cancer with those of patients with benign diseases of the same organs. Terepka and Waterhouse, ${ }^{\circ}$ Theologides et $a l^{10}$ and Costa $e t a l^{11}$ reported on patients with cancer but, while speculating on possible cancer-specific mechanisms for reduced food intake, did not include control subjects. Because of the increasing use of nutritional repletion as an adjuvant to conventional cancer treatment and because many current nutritional regimens are expensive and complex, we thought it important to know the pattern and extent of the dietary deficiency likely to be seen in patients with cancer.

\section{Patients and methods}

We studied 66 patients with gastrointestinal disease. Forty-two had malignancies ( 26 men, 16 women) and 24 benign diseases (10 men, 14 women). The mean ages of the patients with cancer were 61 (range 36-88) for men and 63 (range 24-84) for women; and of those with benign diseases 51 (range 35-77) for men and 63 (range 24-84) for women. The commonest lesions were carcinomas of the oesophagus, stomach, colon, and rectum; peptic oesophageal stricture; peptic ulcer of the stomach and duodenum; and diverticular disease

Northwick Park Hospital and Clinical Research Centre, Harrow, MiddleseX HA1 3UJ

M BURKE, MB, FRCS, clinical research officer and honorary surgical registrar ELAINE I BRYSON, BSC, SRD, dietitian

A E KARK, MD, FRCS, consultant surgeon of the colon. There were no significant differences in the distributions of upper and lower gastrointestinal lesions between any of the groups. Patients with acute presentations were excluded.

We studied the patients by using a modification of a research dietary interview technique. ${ }^{12}$ All patients were interviewed by a dietitian (EIB) either as inpatients or during a special visit to the hospital. The dietitian did not know the patients' diagnoses. Patients with language difficulties or unusual diets were excluded from the study.

Interviews began with an introductory discussion, during which the dietitian sought to win the patient's confidence and learn about his social and economic background. The patient was then shown a series of standard samples of commonly used foods and household measures, which were subsequently used for reference. Systematic questions were then asked about each meal and snack eaten by the subject during seven days before admission to hospital. Questioning technique was adjusted for each patient, care being taken to avoid leading questions. A cross-check was carried out by asking the patients to estimate quantities of certain foods they ate each week. When this disagreed with the assessment further checks were made to improve accuracy. Each interview took 45-60 minutes. Mean daily intakes of protein, fat, and carbohydrate and total daily energy intakes were calculated from food tables. ${ }^{13}$ Results were expressed as absolute amounts and in terms of body weight and fat-free mass estimated from total body potassium (TBK). ${ }^{14}$ Protein and energy intakes were also expressed as percentages of DHSS recommended allowances for individuals of the same age and sex..15

TBK was measured by whole-body $40 \mathrm{~K}$ gamma spectrometry. Total body water (TBW) was measured by deuterium oxide or titrated water dilution. Resting metabolic rate was measured using the "oxylog" machine. ${ }^{16}$

For the purpose of analysis patients were grouped into those with benign and those with malignant disease and subdivided according to sex and the presence or absence of weight loss on the basis of symptoms. No selection was made based on the degree of weight loss, since this is a function of the duration as well as the severity of energy deficit and our patients often did not give a precise history of the duration of their symptoms.

Comparisons between groups were made with Wilcoxon's rank sum test.

\section{Results}

Table I shows the mean weights and mean per cent of ideal weight of the groups. There were no significant differences between equivalent groups with cancer and benign diseases, but differences between men and women and between patients who lost weight and those who did not were significant $(p<0.05)$. Thus the patients with benign and malignant diseases were of comparable nutritional state and seemed to be from a relatively obese population.

TABLE I-Mean weights of patients (and ranges)

\begin{tabular}{|c|c|c|c|c|c|c|c|}
\hline & \multicolumn{3}{|c|}{ Men } & \multicolumn{3}{|c|}{ Women } \\
\hline & & $\mathrm{n}$ & $\underset{(\mathbf{k g})}{\text { Weight }}$ & $\begin{array}{c}\% \text { ideal } \\
\text { body weight }\end{array}$ & $\mathrm{n}$ & $\underset{(\mathbf{k g})}{\text { Weight }}$ & $\begin{array}{c}\% \text { ideal } \\
\text { body weight }\end{array}$ \\
\hline $\begin{array}{l}\text { No weight loss } \\
\text { Weight loss }\end{array}$ & & $\begin{array}{r}6 \\
24\end{array}$ & $\begin{array}{c}\text { Patie } \\
70 \cdot 6 \\
(63 \cdot 2-75 \cdot 2) \\
63 \cdot 3 \\
(42 \cdot 1-80 \cdot 5)\end{array}$ & $\begin{array}{c}\text { nts with cancer } \\
111 \\
(100-127) \\
97 \cdot 4 \\
(65-133)\end{array}$ & $\begin{array}{r}6 \\
12\end{array}$ & $\begin{array}{c}61 \cdot 9 \\
(57 \cdot 7-66 \cdot 4) \\
49 \cdot 8 \\
(38 \cdot 2-63 \cdot 4)\end{array}$ & $\begin{array}{c}115 \\
(98-127) \\
97 \cdot 3 \\
(77-124)\end{array}$ \\
\hline $\begin{array}{l}\text { No weight loss } \\
\text { Weight loss }\end{array}$ & & $\begin{array}{l}8 \\
4\end{array}$ & $\begin{array}{c}\text { Patients } \\
72 \cdot 9 \\
(61 \cdot 8-83 \cdot 5) \\
61 \cdot 7 \\
(47 \cdot 4-78 \cdot 0)\end{array}$ & $\begin{array}{c}\text { with benign dis } \\
111 \\
(97-124) \\
92 \cdot 5 \\
(70-112)\end{array}$ & $\begin{array}{r}\text { rease } \\
8 \\
6\end{array}$ & $\begin{array}{c}62 \cdot 3 \\
(52 \cdot 1-75 \cdot 1) \\
50 \cdot 4 \\
(40 \cdot 9-63 \cdot 8)\end{array}$ & $\begin{array}{c}113 \\
(99-139) \\
94 \\
(79-114)\end{array}$ \\
\hline
\end{tabular}


Results for men with benign disease who lost weight are excluded from the following analyses because too few were obtained for statistical analysis, but they did not vary from the overall pattern of the other results.

Tables II and III give details of the daily energy and protein

TABLE II-Mean ( $\pm S E$ of mean) energy and protein intakes in men with cancer and benign disease according to weight loss

\begin{tabular}{|c|c|c|c|c|}
\hline & \multicolumn{2}{|c|}{ No weight loss } & \multicolumn{2}{|c|}{ Weight loss } \\
\hline & $\begin{array}{l}\text { Cancer } \\
(n=6)\end{array}$ & $\begin{array}{l}\text { Benign } \\
\text { disease } \\
(\mathrm{n}=8)\end{array}$ & $\begin{array}{c}\text { Cancer } \\
(n=20)\end{array}$ & $\underset{\text { Bisease } \dagger}{\text { Benign }}$ \\
\hline Absolute intake (kJ) & $9009 \pm 891 \cdot 6$ & $\begin{array}{l}\text { nergy } \\
10319 \pm 1111\end{array}$ & $8748 \pm 605$ & \\
\hline 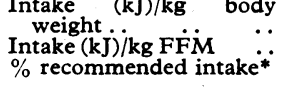 & $\begin{array}{r}127 \cdot 3 \pm 11 \cdot 0 \\
184 \cdot 8 \pm 17 \cdot 7 \\
96 \cdot 0 \pm 8 \cdot 06\end{array}$ & $\begin{array}{r}142 \cdot 3 \pm 14 \cdot 4 \\
198 \cdot 7 \pm 14 \cdot 9 \\
98 \cdot 6 \pm 10 \cdot 6\end{array}$ & $\begin{array}{c}140 \cdot 1 \pm 8 \cdot 1 \\
195 \cdot 7 \pm 11 \cdot 8 \\
86 \cdot 9 \pm 5 \cdot 9\end{array}$ & \\
\hline $\begin{array}{l}\text { Absolute intake (g) } \\
\text { Intake }(\mathrm{g}) / \mathrm{kg} \text { body weight } \\
\text { Intake }(\mathrm{g}) / \mathrm{kg} \text { FFM } \\
\% \text { recommended intake* }\end{array}$ & $\begin{array}{l}71 \cdot 2 \pm 6 \cdot 17 \\
1 \cdot 01 \pm 0 \cdot 08 \\
1 \cdot 46 \pm 0 \cdot 11 \\
127 \cdot 0 \pm 8 \cdot 5\end{array}$ & $\begin{array}{l}\text { rotein } \\
77 \cdot 5 \pm 6 \cdot 4 \\
1 \cdot 07 \pm 0 \cdot 09 \\
1 \cdot 52 \pm 0 \cdot 12 \\
124 \cdot 2 \pm 10 \cdot 1\end{array}$ & $\begin{array}{c}66 \cdot 3 \pm 4 \cdot 2 \\
1 \cdot 07 \pm 0.07 \\
1.50 \pm 0.09 \\
104 \cdot 7 \pm 6.9\end{array}$ & \\
\hline
\end{tabular}

FFM = Fat-free mass

*Intake recommended by DHSS. ${ }^{15}$

$\dagger$ Too few results were obtained for analysis in patients with benign disease who lost weight.

Conversion: SI to traditional units-Energy: $4 \cdot 2 \mathrm{~kJ} \approx 1 \mathrm{kcal}$.

TABLE III-Mean ( $\pm S E$ of mean) energy and protein intakes in women with cancer and benign disease according to weight. loss

\begin{tabular}{|c|c|c|c|c|}
\hline & \multicolumn{2}{|c|}{ No weight loss } & \multicolumn{2}{|c|}{ Weight loss } \\
\hline & $\begin{array}{l}\text { Cancer } \\
(\mathrm{n}=6)\end{array}$ & $\begin{array}{l}\text { Benign } \\
\text { disease } \\
(n=7)\end{array}$ & $\begin{array}{l}\text { Cancer } \\
(n=10)\end{array}$ & $\begin{array}{c}\text { Benign } \\
\text { disease } \\
(n=7)\end{array}$ \\
\hline $\begin{array}{l}\text { Absolute intake }(\mathrm{kJ}) \\
\text { Intake }(\mathrm{kJ}) / \mathrm{kg}\end{array}$ & $9038 \pm 535$ & $\begin{array}{l}\text { Energy } \\
8698 \pm 659\end{array}$ & $5731 \pm 409$ & $6733 \pm 470$ \\
\hline $\begin{array}{l}\text { weight } \\
\text { Intake }(\mathrm{kJ}) / \mathrm{kg} \text { FFM } \\
\% \text { recommended intake* }\end{array}$ & $\begin{array}{l}146 \cdot 6 \pm 9 \cdot 5 \\
216 \cdot 9 \pm 7 \cdot 1 \\
107 \cdot 5 \pm 5 \cdot 26\end{array}$ & $\begin{array}{r}144 \cdot 1 \pm 14.5 \\
207.4 \pm 16.6 \\
99.8 \pm 6.63\end{array}$ & $\begin{array}{r}121 \cdot 4 \pm 11 \cdot 0 \\
176 \cdot 1 \pm 13 \cdot 4 \\
67 \cdot 5 \pm 4 \cdot 40\end{array}$ & $\begin{array}{c}135 \cdot 6 \pm 10 \cdot 8 \\
200 \cdot 6 \pm 9 \cdot 5 \\
80 \cdot 8 \pm 5 \cdot 8\end{array}$ \\
\hline $\begin{array}{l}\text { Absolute intake (g) } \\
\text { Intake }(\mathrm{g}) / \mathrm{kg} \text { body weight } \\
\text { Intake }(\mathrm{g}) / \mathrm{kg} \text { FFM } \\
\% \text { recommended intake }\end{array}$ & $\begin{array}{r}72 \cdot 9 \pm 3.97 \\
1 \cdot 17 \pm 0.06 \\
1 \cdot 75 \pm 0.06 \\
145 \cdot 1 \pm 8 \cdot 3\end{array}$ & $\begin{array}{r}\text { Protein } \\
68 \cdot 6 \pm 4.03 \\
1 \cdot 12 \pm 0.08 \\
1.63 \pm 0.08 \\
132 \cdot 1 \pm 5.73\end{array}$ & $\begin{array}{r}51 \cdot 0 \pm 4 \cdot 14 \\
1 \cdot 08 \pm 0 \cdot 10 \\
1 \cdot 59 \pm 0 \cdot 15 \\
101 \cdot 4 \pm 8 \cdot 54\end{array}$ & $\begin{array}{r}57 \cdot 5 \pm 5 \cdot 9 \\
1 \cdot 15 \pm 0 \cdot 12 \\
1 \cdot 71 \pm 0 \cdot 16 \\
114 \cdot 1 \pm 11 \cdot 3\end{array}$ \\
\hline
\end{tabular}

FFM = Fat-free mass.

Conversion: SI to traditional units-Energy: $4 \cdot 2 \mathrm{~kJ} \approx 1 \mathrm{kcal}$. intakes. The decrease in energy intake in the patients who lost weight was significant only among the women $(p \ll 0.01$ for those with cancer, $\mathrm{p}<0.05$ for those with benign disease), and both these groups took in significantly less than the equivalent men $(p<0.05)$. There were no significant differences between patients with benign and malignant disease. A similar pattern was seen for protein intake, with a significantly lower intake with weight loss in the women with cancer $(p<0.01)$ and the women who lost weight taking in less than the men $(\mathrm{p}<0.05)$.

The daily energy intake/kg body weight ranged from 126 to $147 \mathrm{~kJ}$ (30-35 kcals) $/ \mathrm{kg} /$ day. There were no significant differences between any of the categories of patients, and the men with cancer appeared to reverse the trend seen in the other groups of a slightly reduced intake with weight loss. The pattern for protein intake was identical, with values of $1 \cdot 0-1 \cdot 2 \mathrm{~g} / \mathrm{kg} /$ day and no significant differences between groups.

When energy intake was expressed in terms of fat-free mass there were no significant differences between any of the groups of men, while the women with cancer who did not lose weight took in significantly more than the equivalent men $(p<0.05)$ and the women with cancer who did lose weight $(p<0.02)$. Among the groups who lost weight the sex difference was no longer significant. The pattern for protein intake was similar, but, again, differences between groups were not significant

An indication of the adequacy of the diet and a comparison with that of the general population was sought by comparing our results with DHSS recommended intakes. ${ }^{15}$ Energy intake was around recommended levels in the groups who did not lose weight but fell below this in the groups who lost weight, the fall being significant in women $(p \ll 0.01$ for those with cancer and $p<0.05$ for those with benign diseases). Intakes fell to $55-65 \%$ of recommended levels. This contrasts with findings for protein. All patients who did not lose weight took in much more protein than is recommended (which, moreover, is much more than the basal need), and, although the percentage intake was lower in patients who lost weight, the difference was significant only in the women with cancer $(p<0.025)$. Average intake did not fall below $100 \%$ of recommended allowances in any group.

The differences in daily intake described for protein were mirrored by intakes of fat and carbohydrate (tables IV and V). Lowest fat intakes occurred in women with cancer who lost weight and were significantly less than the intakes in the women $(p<0.01)$ and men $(p \ll 0.01)$ with cancer who did not lose weight. The probabilities for the equivalent differences in carbohydrate intake were $\mathrm{p} \ll 0.01$ and $\mathrm{p} \ll 0.01$. The impression that decreased food intake affects all dietary components equally is confirmed by results in these two tables, which show that the percentage of daily energy derived from each component was the same for all groups.

TABLE IV-Mean ( $\pm S E$ of mean) daily intakes of protein, fat, and carbohydrate and percentages of daily energy derived from these nutrients in men with cancer and benign disease

\begin{tabular}{|c|c|c|c|c|c|c|c|c|c|c|c|c|}
\hline & & & & & & & \multicolumn{3}{|c|}{ Cancer } & \multicolumn{3}{|c|}{ Benign disease } \\
\hline & & & & & & & Protein & Fat & Carbohydrate & Protein & Fat & Carbohydrate \\
\hline $\begin{array}{l}\text { Nutrients (g)/day } \\
\% \text { daily energy }\end{array}$ & $\therefore$ & $\because$ & $\because$ & $\because$ & 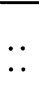 & $\because$ & $\begin{array}{c}71 \cdot 2 \pm 6 \cdot 17 \\
13 \cdot 5 \pm 1 \cdot 26 \\
(n=6)\end{array}$ & $\begin{array}{c}\text { No weight loss } \\
92 \cdot 8 \pm 8 \cdot 8 \\
39 \cdot 0 \pm 0 \cdot 89 \\
(n=6)\end{array}$ & $\begin{array}{c}244 \cdot 0 \pm 17 \cdot 6 \\
46 \cdot 3 \pm 2 \cdot 41 \\
(n=6)\end{array}$ & $\begin{array}{c}77 \cdot 5 \pm 6 \cdot 4 \\
13 \cdot 3 \pm 1 \cdot 25 \\
(n=8)\end{array}$ & $\begin{array}{c}100 \cdot 5 \pm 13 \cdot 4 \\
37 \cdot 3 \pm 2 \cdot 88 \\
(n=8)\end{array}$ & $\begin{array}{c}273 \cdot 0 \pm 42 \cdot 24 \\
43 \cdot 6 \pm 4 \cdot 42 \\
(n=8)\end{array}$ \\
\hline $\begin{array}{l}\text { Nutrients (g)/day } \\
\% \text { daily energy }\end{array}$ & $\because$ & $\begin{array}{l}\cdots \\
\cdots\end{array}$ & $\ddot{x}$ & $\because$ & $\because$ & $\because$ & $\begin{array}{c}66 \cdot 3 \pm 4 \cdot 2 \\
13 \cdot 2 \pm 0 \cdot 95 \\
(n=20)\end{array}$ & $\begin{array}{c}\text { Weight loss } \\
91 \cdot 6 \pm 8 \cdot 4 \\
38 \cdot 9 \pm 2 \cdot 0 \\
\left(\mathrm{n}=20^{*}\right)\end{array}$ & $\begin{array}{c}232 \cdot 5 \pm 16 \cdot 1 \\
46 \cdot 8 \pm 2 \cdot 02 \\
\left(n=20^{*}\right)\end{array}$ & & & \\
\hline
\end{tabular}

*Estimations of nutrients/day based on 19 patients.

TABLE V-Mean ( $\pm S E$ of mean) daily intakes of protein, fat, and carbohydrate and percentages of daily energy derived from these nutrients in women with cancer and benign disease

\begin{tabular}{|c|c|c|c|c|c|c|c|c|c|c|c|c|}
\hline & & & & & & & \multicolumn{3}{|c|}{ Cancer } & \multicolumn{3}{|c|}{ Benign disease } \\
\hline & & & & & & & Protein & Fat & Carbohydrate & Protein & Fat & Carbohydrate \\
\hline $\begin{array}{l}\text { Nutrients (g)/day } \\
\% \text { daily energy }\end{array}$ & $\because$ & $\because$ & $\because$ & $\because$ & $\because$ & 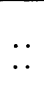 & $\begin{array}{c}72 \cdot 9 \pm 3 \cdot 97 \\
13 \cdot 7 \pm 0 \cdot 8 \\
(n=6)\end{array}$ & $\begin{array}{c}\text { No weight loss } \\
94 \cdot 2 \pm 7 \cdot 3 \\
39 \cdot 2 \pm 1 \cdot 47 \\
(\mathrm{n}=6)\end{array}$ & $\begin{aligned} & 253 \cdot 3 \pm 15 \cdot 1 \\
& 48 \cdot 0 \pm 1 \cdot 73 \\
&(n=6)\end{aligned}$ & $\begin{array}{c}68 \cdot 6 \pm 4 \cdot 03 \\
13 \cdot 3 \pm 0 \cdot 68 \\
(n=7)\end{array}$ & $\begin{array}{c}88 \cdot 0 \pm 9 \cdot 9 \\
37 \cdot 7 \pm 2 \cdot 26 \\
(n=7)\end{array}$ & $\begin{aligned} & 247 \cdot 7 \pm 18 \cdot 5 \\
& 47 \cdot 9 \pm 1 \cdot 99 \\
&(\mathrm{n}=7)\end{aligned}$ \\
\hline $\begin{array}{l}\text { Nutrients (g)/day } \\
\% \text { daily energy }\end{array}$ & $\ddot{x}$ & 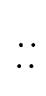 & 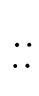 & $\because$ & 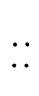 & $\because$ & $\begin{array}{c}51 \cdot 0 \pm 4 \cdot 14 \\
15 \cdot 3 \pm 1 \cdot 03 \\
(n=10)\end{array}$ & $\begin{array}{c}\text { Weight loss } \\
59 \cdot 1 \pm 6 \cdot 3 \\
39 \cdot 0 \pm 3 \cdot 15 \\
(\mathrm{n}=10)\end{array}$ & $\begin{array}{c}152 \cdot 4 \pm 18 \cdot 0 \\
46 \cdot 2 \pm 3 \cdot 54 \\
(n=10)\end{array}$ & $\begin{array}{c}57 \cdot 5 \pm 5 \cdot 9 \\
14 \cdot 6 \pm 1 \cdot 48 \\
(n=7)\end{array}$ & $\begin{array}{c}70 \cdot 6 \pm 6 \cdot 0 \\
39 \cdot 4 \pm 1 \cdot 31 \\
(n=7)\end{array}$ & $\begin{array}{c}187 \cdot 0 \pm 15 \cdot 0 \\
46 \cdot 6 \pm 2 \cdot 66 \\
(n=7)\end{array}$ \\
\hline
\end{tabular}


In the patients with cancer the effect of the site of the primary tumour on dietary intake seemed to be of minor importance. Table VI shows the intakes of the patients whose tumour bulk allowed them to be clearly separated into groups with upper and lower gastrointestinal tumours. The lower mean intakes in the groups with upper gastrointestinal lesions were not significant.

Table VII shows the intakes in the patients with cancer according to the degree of spread of the tumour. When grouped in this way, men tended to take in more than women and patients with local

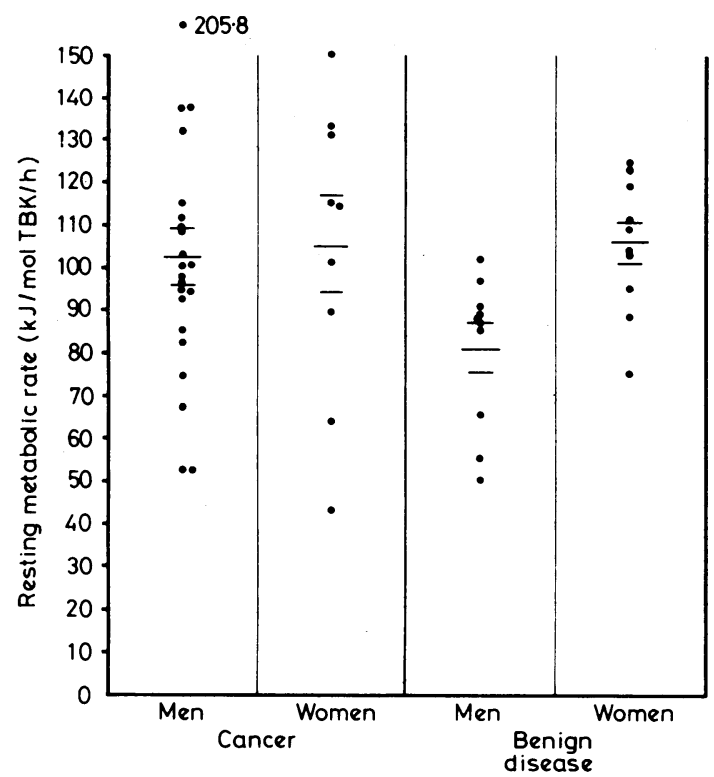

FIG I-Resting metabolic rate in 51 patients with cancer or benign disease.

$\mathrm{TBK}=$ Total body potassium

Conversion: $S I$ to traditional units-Potassium: $1 \mathrm{~mol}=$ 1 Eq. tumours more than those with advanced, but the differences were not significant.

Dietary data should not be considered separately from measurements of metabolic rate. Figure 1 shows the distribution of measurements of resting metabolic rate in 51 of the patients. Men with

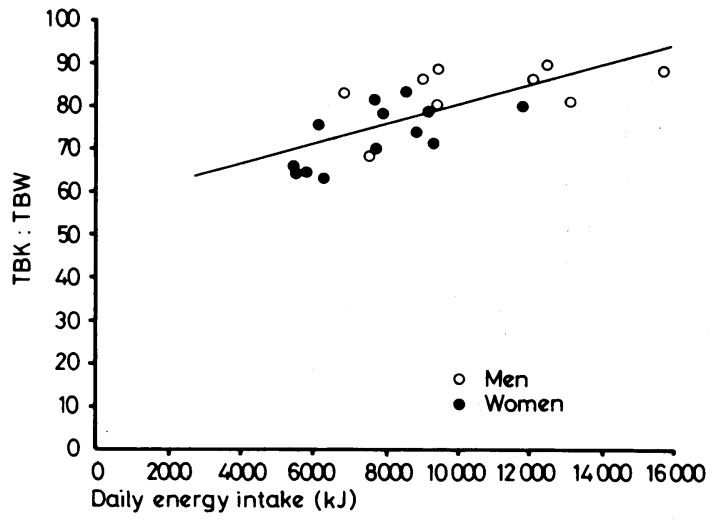

FIG 2-Correlation between daily energy intake and nutritional state as defined by ratio of total body potassium (TBK) to total body water (TBW) (normal range 76.9891.46 men, 68.55-86.67 women). in patients with benign gastrointestinal disease.

Conversion: SI to traditional units-Energy: $4 \cdot 2 \mathrm{~kJ} \approx 1$ kcal.

benign disease had a significantly lower rate than men with cancer $(p<0.05)$ and women with benign disease $(p<0.01)$, but there were no significant differences between any other groups.

As no accurate information on duration of symptoms was available the relation between food intake and nutritional state as defined by the ratio TBK:TBW was examined (this ratio falls with under nutrition). Figures 2 and 3 show the correlations between daily energy

TABLE VI-Effect of site of primary tumour on mean daily dietary intake

\begin{tabular}{|c|c|c|c|c|c|c|c|c|c|c|c|c|c|c|}
\hline & & & \multicolumn{6}{|c|}{ Upper gastrointestinal tumour } & \multicolumn{6}{|c|}{ Lower gastrointestinal tumour } \\
\hline & & & \multicolumn{3}{|c|}{ Energy } & \multicolumn{3}{|c|}{ Protein } & \multicolumn{3}{|c|}{ Energy } & \multicolumn{3}{|c|}{ Protein } \\
\hline & & & $\underset{(\mathrm{kJ})}{\text { Absolute }}$ & $\mathrm{kJ} / \mathrm{kg}$ & $\begin{array}{l}\mathrm{kJ} / \mathbf{k g} \\
\mathrm{FFM}\end{array}$ & $\begin{array}{c}\text { Absolute } \\
(\mathbf{g})\end{array}$ & $\mathbf{g} / \mathbf{k g}$ & $\begin{array}{l}\mathbf{g} / \mathbf{k g} \\
\mathrm{FFM}\end{array}$ & $\underset{(\mathrm{kJ})}{\text { Absolute }}$ & $\mathrm{kJ} / \mathrm{kg}$ & $\begin{array}{l}\mathbf{k j} / \mathbf{k g} \\
\text { FFM }\end{array}$ & $\underset{(\mathrm{g})}{\text { Absolute }}$ & $\mathrm{g} / \mathrm{kg}$ & $\begin{array}{l}\text { g/kg } \\
\text { FFM }\end{array}$ \\
\hline $\begin{array}{l}\text { No of patients } \\
\text { Mean intake } \\
\text { SD } \\
\text { SE of mean }\end{array}$ & $\begin{array}{l}\cdots \\
\cdots \\
\cdots\end{array}$ & $\begin{array}{l}\ldots \\
\cdots \\
\cdots\end{array}$ & $\begin{array}{r}12 \\
8446 \\
2785 \\
802\end{array}$ & $\begin{array}{r}12 \\
133.6 \\
31.9 \\
9.2\end{array}$ & $\begin{array}{l}12 \\
187 \cdot 3 \\
52 \cdot 1 \\
15 \cdot 1\end{array}$ & $\begin{array}{r}12 \\
63.5 \\
22.5 \\
6.5\end{array}$ & $\begin{array}{c}12 \quad M \\
1.00 \\
0.32 \\
0.09\end{array}$ & $\begin{array}{l}12 \\
1.41 \\
0.43 \\
0.12\end{array}$ & $\begin{array}{r}12 \\
9064 \\
2566 \\
739\end{array}$ & $\begin{array}{l}12 \\
137 \cdot 3 \\
36 \cdot 1 \\
10 \cdot 4\end{array}$ & $\begin{array}{r}12 \\
192 \cdot 4 \\
49 \cdot 1 \\
14 \cdot 3\end{array}$ & $\begin{array}{r}12 \\
69 \cdot 4 \\
12 \cdot 8 \\
3 \cdot 7\end{array}$ & $\begin{array}{c}12 \\
1.04 \\
0 \cdot 28 \\
0.08\end{array}$ & $\begin{array}{r}12 \\
1.49 \\
0.32 \\
0.09\end{array}$ \\
\hline $\begin{array}{l}\text { No of patients } \\
\text { Mean intake } \\
\text { SD } \\
\text { SE of mean }\end{array}$ & $\begin{array}{l}\cdots \\
\because \\
\cdots\end{array}$ & $\begin{array}{l}\ldots \\
\because \\
\therefore\end{array}$ & $\begin{array}{r}7 \\
6686 \\
1583 \\
601\end{array}$ & $\begin{array}{r}7 \\
137 \cdot 8 \\
34 \cdot 0 \\
13 \cdot 0\end{array}$ & $\begin{array}{c}7 \\
199 \cdot 1 \\
37 \cdot 4 \\
14 \cdot 3\end{array}$ & $\begin{array}{r}7 \\
52 \cdot 6 \\
14 \cdot 6 \\
5 \cdot 5\end{array}$ & $\begin{array}{l}7^{W o} \\
1 \cdot 09 \\
0 \cdot 38 \\
0 \cdot 14\end{array}$ & $\begin{array}{c}7 \\
1.61 \\
0.55 \\
0 \cdot 21\end{array}$ & $\begin{array}{r}5 \\
7489 \\
2461 \\
928\end{array}$ & $\begin{array}{r}5 \\
130 \cdot 2 \\
24 \cdot 4 \\
10 \cdot 9\end{array}$ & $\begin{array}{r}5 \\
191 \cdot 5 \\
24 \cdot 8 \\
8 \cdot 1\end{array}$ & $\begin{array}{c}5 \\
68 \cdot 0 \\
17 \cdot 9 \\
8 \cdot 1\end{array}$ & $\begin{array}{c}5 \\
1 \cdot 18 \\
0 \cdot 10 \\
0 \cdot 04\end{array}$ & $\begin{array}{c}5 \\
1 \cdot 76 \\
0 \cdot 25 \\
0 \cdot 11\end{array}$ \\
\hline
\end{tabular}

FFM = Fat-free mass

Conversion: SI to traditional units-Energy: $4 \cdot 2 \mathrm{~kJ} \approx 1 \mathrm{kcal}$

TABLE VII-Effect of degree of spread of tumour on mean daily dietary intake

\begin{tabular}{|c|c|c|c|c|c|c|c|c|c|c|c|c|c|c|}
\hline & & & \multicolumn{6}{|c|}{ Stage $1^{*}$} & \multicolumn{6}{|c|}{ Stage $3 \dagger$} \\
\hline & & & \multicolumn{3}{|c|}{ Energy } & \multicolumn{3}{|c|}{ Protein } & \multicolumn{3}{|c|}{ Energy } & \multicolumn{3}{|c|}{ Protein } \\
\hline & & & $\underset{(\mathrm{kJ})}{\text { Absolute }}$ & $\mathrm{kJ} / \mathbf{k g}$ & $\begin{array}{l}\mathbf{k J} / \mathbf{k g} \\
\text { FFM }\end{array}$ & $\begin{array}{l}\text { Absolute } \\
\text { (g) }\end{array}$ & $\mathbf{g} / \mathbf{k g}$ & $\begin{array}{l}\text { g/kg } \\
\text { FFM }\end{array}$ & $\underset{(\mathrm{kJ})}{\text { Absolute }}$ & $\mathrm{kJ} / \mathrm{kg}$ & $\begin{array}{l}\mathbf{k J} / \mathbf{k g} \\
\text { FFM }\end{array}$ & $\begin{array}{l}\text { Absolute } \\
\text { (g) }\end{array}$ & $\mathrm{g} / \mathrm{kg}$ & $\begin{array}{l}\mathbf{g} / \mathbf{k g} \\
\text { FFM }\end{array}$ \\
\hline $\begin{array}{l}\text { No of patients } \\
\text { Mean intake } \\
\text { SD } \\
\text { SE of mean }\end{array}$ & $\begin{array}{l}\because \\
\because \\
\therefore\end{array}$ & $\begin{array}{l}\cdots \\
\because \\
\cdots\end{array}$ & $\begin{array}{r}13 \\
9227 \\
2108 \\
584\end{array}$ & $\begin{array}{r}13 \\
146 \cdot 6 \\
26 \cdot 5 \\
7 \cdot 1\end{array}$ & $\begin{array}{r}13 \\
205 \cdot 4 \\
42 \cdot 3 \\
11 \cdot 8\end{array}$ & $\begin{array}{r}13 \\
66 \cdot 4 \\
15 \cdot 4 \\
4 \cdot 3\end{array}$ & $\begin{array}{c}13 \\
1 \cdot 10 \\
0 \cdot 31 \\
0 \cdot 09\end{array}$ & $\begin{array}{c}13 \\
1.57 \\
0.31 \\
0.09\end{array}$ & $\begin{array}{r}10 \\
8728 \\
3087 \\
974\end{array}$ & $\begin{array}{r}10 \\
133 \cdot 6 \\
40.9 \\
12 \cdot 9\end{array}$ & $\begin{array}{c}10 \\
187 \cdot 3 \\
59 \cdot 3 \\
18 \cdot 8\end{array}$ & $\begin{array}{l}10 \\
66 \cdot 3 \\
23 \cdot 6 \\
7 \cdot 5\end{array}$ & $\begin{array}{l}10 \\
1.01 \\
0.34 \\
0.11\end{array}$ & $\begin{array}{c}10 \\
1.44 \\
0.51 \\
0.16\end{array}$ \\
\hline $\begin{array}{l}\text { No of patients } \\
\text { Mean intake } \\
\text { SD } \\
\text { SE of mean }\end{array}$ & $\begin{array}{l}\cdots \\
\cdots \\
\cdots\end{array}$ & $\begin{array}{l}\because \\
\because \\
\because\end{array}$ & $\begin{array}{r}8 \\
7480 \\
1982 \\
701\end{array}$ & $\begin{array}{r}8 \\
138 \cdot 6 \\
33 \cdot 4 \\
10 \cdot 6\end{array}$ & $\begin{array}{r}8 \\
212.9 \\
30.9 \\
10.9\end{array}$ & $\begin{array}{c}8 \\
62 \cdot 3 \\
13 \cdot 4 \\
4 \cdot 7\end{array}$ & $\begin{array}{l}8 \quad W \\
1 \cdot 17 \\
0 \cdot 32 \\
0 \cdot 11\end{array}$ & 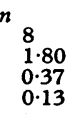 & $\begin{array}{r}7 \\
6300 \\
2285 \\
865\end{array}$ & $\begin{array}{r}7 \\
118 \cdot 0 \\
31 \cdot 0 \\
11 \cdot 7\end{array}$ & $\begin{array}{c}7 \\
168 \\
39 \cdot 9 \\
15 \cdot 1\end{array}$ & $\begin{array}{c}7 \\
59 \cdot 4 \\
17 \cdot 6 \\
6 \cdot 6\end{array}$ & $\begin{array}{l}7 \\
1 \cdot 11 \\
0 \cdot 18 \\
0 \cdot 07\end{array}$ & $\begin{array}{l}7.59 \\
1.59 \\
0 \cdot 27 \\
0 \cdot 10\end{array}$ \\
\hline
\end{tabular}

* Stage $1=$ No tumour spread beyond organ of origin. 


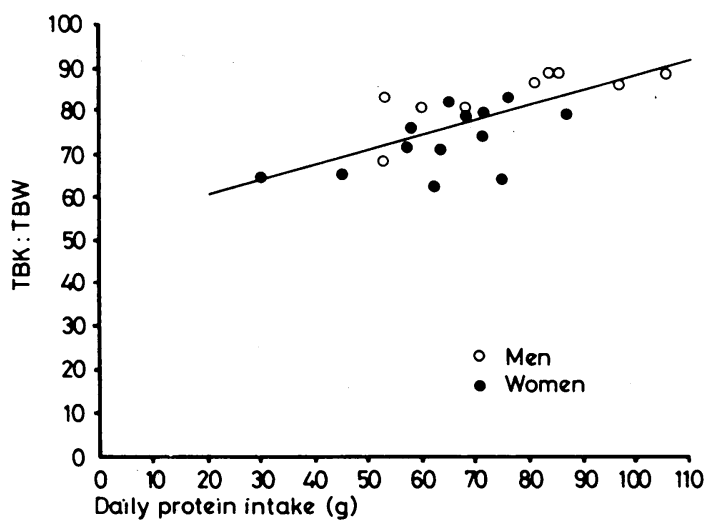

FIG 3-Correlation between daily protein intake and nutritional state as defined by ratio of total body potassium (TBK) to total body water (TBW) in patients with benign disease.

and protein intakes and nutritional state in patients with benign disease. The relations may be described by the regression equations

$$
\begin{gathered}
\text { TBK (mmol): TBW }(\mathrm{kg})=0.0023 \text { daily energy intake }(\mathrm{kJ})+57.28 \\
(\mathrm{n}=22 ; \mathrm{r}=0.698: \mathrm{p}<0.001) \\
\text { TBK (mmol): TBW }(\mathrm{kg})=0.34 \text { daily protein intake }(\mathrm{g})+53.70 \\
(\mathrm{n}=22 ; \mathrm{r}=0.69: \mathrm{p}<0.01) .
\end{gathered}
$$

The relation between nutritional state and food intake in cancer is much weaker, the equivalent equations being

$$
\begin{gathered}
\text { TBK (mmol): TBW }(\mathrm{kg})=0.00002 \text { daily energy intake }(\mathrm{kJ})+73.42 \\
(\mathrm{n}=42 ; \mathrm{r}=0.019: \text { not significant }) \\
\text { TBK (mmol): TBW }(\mathrm{kg})+0.13 \text { daily protein intake }(\mathrm{g})+65.06 \\
(\mathrm{n}=42 ; \mathrm{r}=0.26: \mathrm{p}<0.05) .
\end{gathered}
$$

For both energy and protein intakes there was a significant difference in the correlation coefficients between the patients with cancer and benign disease ( $p<0.003$ for energy; $p<0.05$ for protein).

\section{Discussion}

Weight loss results from an imbalance of energy expenditure over intake. There has been a widely held clinical impression that weight loss in patients with cancer is disproportionate to their reduction in energy intake, but this has rarely been systematically investigated. Most studies have been concerned with energy expenditure, and results have been conflicting. Possible reasons for this are that tumours of widely different biological types and affecting different organ systems have often been grouped together and that when controls have been used they have often been inappropriate, such as the chronically bed-ridden, immobile subjects used by Warnold et al. ${ }^{\circ}$ We tried to avoid this problem by studying patients with the common adenocarcinomas of the gastrointestinal tract and comparing them with patients with benign disease at the same sites. Patients were studied at presentation for surgery, usually at the time of initial diagnosis in those with cancer. In this respect they were more typical of patients facing general surgeons than the subjects with advanced undernutrition in some other studies. ${ }^{6}$ This is reflected in the high ratio of weight to ideal weight in our patients. Many patients who lost weight would not have been classified as undernourished on this basis. We assumed, however, that daily deficit could be as great in mildly undernourished patients with a short history as in severely undernourished patients with a long history. This approach was justified to some extent by our finding that stage of disease does not greatly influence energy intake. This, however, is only a rough guide, since the relation between disease stage and duration probably varies with individual tumours.

An important drawback in studies on energy intake has been the inaccuracy of most existing methods of assessing un- restrained patients. This could lead to important errors when energy balance is to be accurately measured in a few patients. More accurate methods entail observing the patient under strictly controlled hospital conditions or, at least, stationing an observer at his home or workplace. Inevitably, this has the effect of altering his awareness of his diet, so that the end result may reflect his normal intake no more accurately than a skilfully conducted recall interview. We chose this method since it was most suitable for the time and manpower we had available. Since one of us was regularly using the technique with some skill, we assumed that errors due to interviewing technique were constant and in the same direction. We assumed patient errors to be random. Thus the method is not accurate for individuals but may justifiably be used to compare groups.

Throughout the study dietary changes with weight loss were more pronounced in women, especially those with cancer. The results do not exclude the possibility that this apparent sex difference is due to spuriously low intakes in the men with cancer who did not lose weight. This might have been due to deliberately or accidentally inaccurate recall by this group, failure to notice or admit weight loss by some of them, or an accurately assessed reduction in intake without a concomitant weight loss. This might occur if loss of lean tissue and fat was obscured by water retention. While accounting for the low intakes in this group, however, this hypothesis would not explain why they were lower than those in the group who lost weight.

Apart from these differences between men and women, the similarity in mean intakes between the groups in terms of body weight and fat-free mass irrespective of weight loss is remarkable in view of the wide range of results. This suggests a relation between diet and body size in patients with both cancer and benign disease. In the patients with cancer tumour site did not appear to affect this relation, but the differences between patients with localised and advanced tumours, though not statistically significant, were appreciable, and further research is needed before an altered relation between diet and body composition in advanced cancer may be definitely excluded.

Methods of predicting body composition, including fat-free mass, derived from normal subjects may not be applicable in the undernourished. For this reason we examined the relation of food intake to body composition using the ratio of TBK to TBW. This ratio falls with weight loss, since TBK decreases with decreasing cell mass while TBW may even increase owing to retention of water in the extracellular phase. ${ }^{17}$

Our results show good correlation between reduced dietary intake and altered body composition in the benign group but a disturbance of this relation in the patients with cancer. The ratio of TBK to TBW has a theoretical and actual upper limit of about $90 \mathrm{mmol}(\mathrm{mEq}) / \mathrm{kg}$ in our laboratory, so the relation cannot be truly linear at high intakes. In practice, however, this limit is rarely reached even at dietary intakes of up to $16000 \mathrm{~kJ}(3809 \mathrm{kcal})$ and $110 \mathrm{~g}$ protein daily. Intakes above this are rare in non-obese people of normal muscular stature. The ratio of TBK to TBW is lower in women than men. ${ }^{18}$ If the women had also had lower dietary intakes this might have produced a spurious positive correlation. No significant differences in intakes were found, however, and the correlation coefficients for energy and protein intakes with TBK to TBW were significant for men and women with benign disease (men $(n=9)$ : $r=0.59,0.1>p>0.05$ and $r=0.73, p<0.05$; women $(n=13)$ : $r=0.678, p<0.05$ and $r=0.58, p<0.05)$. Thus there appears to be a significant difference between patients with cancer and benign disease in this respect. Our studies of metabolic rate do not support the hypothesis that hypermetabolism is a significant factor in this phenomenon. It is possibly due to impaired absorption or enteric nutrient losses in the patients with cancer.

With regard to nutrient intake and energy expenditure patients with cancer who lost weight were indistinguishable from patients with benign disease. Absolute protein deficiency was rare. The main dietary defect seemed to be an.imbalance 
between protein and energy intakes, probably arising accidentally owing to an overall decrease in intake of our protein-rich Western diet such that energy intake became inadequate while protein intake was maintained at otherwise ample levels. The practical importance of this is that for most patients it may be sufficient to supplement their self-selected oral diet with an easily assimilated energy source administered by fine nasogastric tube if nutritional repletion is thought desirable. The difficulties and expense of many parenteral feeding regimens and the impossibility of persuading anorexic patients with cancer voluntarily to increase their intake would thus be avoided.

Mean intakes in the patients who lost weight were around $126-147 \mathrm{~kJ}$ energy (30-35 kcals) and $1-1 \cdot 2 \mathrm{~g}$ protein $/ \mathrm{kg}$ body weight daily. Refeeding regimens that aim for $168 \mathrm{~kJ}$ (40 kcal) and $1 \mathrm{~g}$ protein $/ \mathrm{kg}$ body weight/day probably do not achieve much more than these levels, allowing for shortfall in administration. This emphasises the error in using fixed formulae based on body weight to prescribe nutritional treatment. The severely undernourished patient needs higher intakes to reverse his metabolic changes than those that are sufficient to maintain body mass in the mildly undernourished, particularly if a tumour or sepsis is present. This is supported by the findings of some groups that intravenous feeding in undernourished patients undergoing surgery arrested further deterioration of their body composition but did not reverse changes that had already occurred, any weight gain being due to water retention. ${ }^{19} 20$

Requests for reprints should be addressed to MB.

\section{References}

1 Warren S. The immediate causes of death in cancer. Am $\mathcal{F}$ Med Sci 1932;184:610-5.

2 Boothby WM, Sandiford I. Summary of the basal metabolism data on 8614 subjects with especial reference to the normal standards for the estimation of BMR. $\mathcal{F}$ Biol Chem 1922;54:783-803
${ }^{3}$ Minot GR, Means JH. The metabolism-pulse ratio in exophthalmic goitre and leukaemia. Arch Intern Med 1924;32:576-80.

4 Silver S, Poroto P, Crohn EB. Hypermetabolic states without hyperthyroidism (non-thyrogenous hypermetabolism). Arch Intern Med $1950 ; 85: 479-82$.

5 Waterhouse CL, Fenninger LD, Keutmann EK. Nitrogen exchange and caloric expenditure in patients with malignant neoplasm. Cancer $1951 ; 4: 500-14$

6 Terepka AR, Waterhouse C. Metabolic observations during the force feeding of patients with cancer. Am F Med 1956;20:225-38.

7 Watkin DM. Nitrogen balance as affected by neoplastic disease and its therapy. Am f Clin Nutr $1961 ; 9: 446-60$.

8 Watkin DM, Steinfeld JL. Nutrient and energy metabolism in patients with and without cancer during hyperalimentation with fat administered intravenously. Am $\mathcal{F}$ Clin Nutr 1965;16:182-212.

${ }^{9}$ Warnold I, Lundholm K, Schersten T. Energy balance and body composition in cancer patients. Cancer Res $1978 ; 38: 1801-2$

10 Theologides A, Ehlert J, Kennedy BJ. The calorie intake of patients with advanced cancer. Minn Med 1976;59:526-9.

11 Costa G, Lyles K, Ullich L. Effects of human and experimental cancer on the conversion of ${ }^{14} \mathrm{C}$ tripalmitin to ${ }^{14} \mathrm{CO}_{2}$. Cancer $1976 ; 38: 1259-65$.

12 Burke BS. The dietary history as a tool in research. $\mathrm{f} \mathrm{Am} \mathrm{Diet} \mathrm{Assoc}$ 1947;23:1041-6.

${ }^{13}$ McCance RA, Widdowson EM. The composition of food. MRC Special Report series, vol 297. London: HMSO, 1960.

14 Womersley J, Durnin JVGA, Boddy $\mathrm{K}$, Mahaffey $M$. Influence of muscular development, obesity and age on the fat free mass of adults. f Appl Physiol 1976;41:223-9.

${ }^{15}$ DHSS, Recommended intakes of nutrients for the United Kingdom. Reports on Public Health and Medical Subjects, No 120. London: DHSS, 1969.

${ }^{16}$ Humphrey SJE, Wolff HS. The Oxylog. F Physiol 1977;267:12P.

17 Moore FD, Olesen KH, McMurray JD, Parker HV, Boyle MR, Boyden $\mathrm{CM}$. The body cell mass and its supporting environment: body composition in health and disease. Philadelphia: Saunders, 1963.

18 Forbes GBF, Schultz F, Cafarelli C, Amirhakmi GH. Effects of body size on $40 \mathrm{~K}$ measurement in the whole body counter (tilt chair technique). Health Phys 1968;15:435-42.

19 Hill GL, McCarthy ID, Collins JP, Smith AH. A new method for the rapid measurement of body composition in critically ill surgical patients. $\operatorname{Br} \mathcal{F}$ Surg 1978;65:732-5.

${ }^{20}$ Schizgal HM, Spanier AH, Kurtz RS. Effect of parenteral nutrition on body composition in the critically ill patient. Amf Surg 1976;131:156-61.

(Accepted 26 October 1979)

黑

ONE HUNDRED YEARS AGO An inquiry, that seems to have excited keen interest in the West of England, was held at Brislington, near Bristol, on the 3rd and 4th of February, before Mr Norris Nicholson, one of the Masters in Lunacy. It had reference to the mental condition of the Rev Walter St Aubyn Basset of Treharrock, a member of an influential Cornish family, in which unhappily insanity has not been unknown, as the father of the alleged lunatic died by his own hand, and his elder brother was for many years an inmate of a private asylum in Sussex. Mr Basset, who was at one time rector of West Buckland, in Devon, but who since 1873 has resided on an estate which he had acquired in North Cornwall, has been eccentric, it was stated, ever since he was a grown man. For several years past, he has laboured under a variety of delusions. This point was undisputed, and was indeed established by the defendant himself, who, when skilfully examined by the Master in the presence of the jury, gave utterance to a number of beliefs which were unmistakably the offspring of a diseased mind. He stated that a conspiracy existed against the Basset family; that a large number of persons in the kingdom were emasculated, and sought to reduce others to their own condition; and that he was followed by spies, whom he called "runners," who went about in towns with hoods over their heads. The medical witnesses called on behalf of the defendant-Drs Beddoe and Brittan of Bristol-testified to his delusions, and gave their opinion that he was of unsound mind. The question at issue was, not really whether Mr Basset was of unsound mind and has delusions, but whether his mental unsoundness and delusions were of such a character as to render him dangerous and incapable of managing his own affairs. Mr Bucknill, who appeared for Mr Basset, laboured, with much ingenuity and zeal, to convince the jury that his client was a gentleman with some odd notions of his own, but of a peaceful disposition, and with abundant capacity to control himself and to look after his property. We are not surprised, however, that he did not succeed in doing so.

$\mathrm{Mr}$ Basset's delusions were clearly united with vindictive feelings towards his supposed enemies, and expressed in very significant phrases. He intimated that he wanted the conspirators "killed respectively," and that he thought $\mathrm{Mr}$ Arch might be disposed of at a cost of $£ 20$, and he made use of words which conveyed the idea that he meditated mischief to his nephew. He went on his hands and knees in his own kitchen, with an open pruning-knife in his hand. Armed with a knife and pistol, he searched the cliffs in the neighbourhood of his residence for the ubiquitous "runners," who watched his premises and hid in clefts of the wall. True, an effort was made to explain and refine away the compromising language which $\mathrm{Mr}$ Basset had used, and his damaging actions. It was shown that Treharrock is a lonely place and was sometimes visited by objectionable persons, against whom it might be proper to take precautions; and it was alleged that the words used by the defendant with reference to his nephew were simply, "This property will come to me when that brat is dead," and involved no menace. Mr Basset's own counsel, however, admitted that he had negotiated for the purchase of a pistol; and it is surely a suspicious circumstance that a clergyman, harbouring numerous morbid ideas, should be desirous of possessing himself of such a weapon. Dr Savage of Bethlem Hospital, who had examined $\mathrm{Mr}$ Basset, pronounced him dangerous to any one he fancied to be injuring him, and recorded his belief that he is suffering from chronic incurable insanity. Mr Bucknill's defence of Mr Basset was most able and spirited; but we venture to think he must have himself experienced a feeling of relief when the verdict of the jury was announced, to the effect that $\mathrm{Mr}$ Basset is a person of unsound mind and incapable of managing his own affairs.

It may, we think, be fairly argued that $\mathrm{Mr}$ Basset was a dangerous lunatic and required restraint. He was scattering broad-cast accusations of an atrocious kind, and insinuations against a number of persons, some of exalted and some of lowly rank. He was denouncing them to the police, to the Home Secretary, and the Bishop of London. Such proceedings are well calculated to lead to a breach of the peace, and are certainly most annoying to those who are affected by them. Certain parts of the most insane statements sound sane enough, and are apt to be believed, and thus actual injury may accrue; and even when that is not the case, much chagrin is occasioned. It is not to be tolerated that a lunatic is to traduce his friends and neighbours, right and left, and to go on doing so, as long as he does not commit a murderous assault. (British Medical fournal, 1880.) 